Queen Victoria Museum and Art Gallery, Launceston, Tasmania

THe Queen Victoria Museum and Art Gallery at Launceston, Tasmania, has completed an interesting addition to its activities by the opening of the Cradle Mountain Trailside Museum, the first of its kind in Australia (Annual Report, 1962-63. Pp. 12. Launceston: Queen Victoria Museum and Art Gallery, 1964). In a building of native pine, and with exhibits pre-fabricated in Launceston, the Museum depicts most aspects of the fauna, flora, geology and natural features of the Cradle Mountain area. A small annexe to the Museum building is used as a laboratory, and surveys of the flora and fauna of the district are in progress. The Chinese Joss House is now equipped with an automatic commentary system brought into action by pressing a button which, with lighting, produces a realistically dramatic effect. Agreement in principle has been reached between the City Council and the Minister for Education regarding the installation of a planetarium in the Museum.

\section{Concrete in Construction of the New Forth Road Bridge}

"ON 4th September 1964, H.M. the Queen opened the new Forth road bridge. In The Times of the following day British Railways were quoted as calling it 'the slender concrete daughter' of their 'steel lady of the Forth'." Thus, the opening paragraph in an article entitled "The Forth bridge and the bridges on its approach roads" (Concrete Quarterly, No. 63; October-December 1964; Cement and Conerete Association, 52 Grosvenor Gardens, London, S.W.1). This is almost a classic example of official understatement, as this article goes on to demonstrate. The new Forth road bridge may be the longest steel suspension bridge in Europe, but without the 210,000 tons of concrete used in its construction ". . . in providing the foundations for the main towers, the massive anchorage plugs for the cables, the side towers, and the approach viaducts", it obviously could not exist. Apart from the splendid design of the bridge itself, nearly nine miles in all of new dual-carriageway approach roads (to motorway standards and with grade separation at junctions) had to be constructed, involving spanning by twenty-four bridges, largely in reinforced concrete, before the new bridge could possibly fulfil its maximum functions. In this article the supporting road-works are rightly given prominence, especially the bridges on the approach roads which, as the illustrations show, are refreshingly variable in design and finish and are undoubtedly "... in themselves a very fine addition to the rapidly lengthening roll-call of good road-bridges in Great Britain". The south approach road, 4.5 miles from just inside the city boundary of Edinburgh, involves 3 miles of subsidiary roads in which system there are nine major bridges, two pedestrian subways and a number of culverts. Featured here is the new concrete Cramond Bridge, replacing Rennie's old stone bridge; the two-level intorchange junctions at Burnshot, Dolphington and Echline; and the bridge over tho main Forth railway lines at Dalmeny. The north approach road, 4 miles, is also designed substantially to motorway standards, and includes two-level junctions at Ferry Toll and Admiralty, and a remarkable two-level junction at Masterton, deseribed as ". . . the most important of all the bridge-works on the northern approach ... the Masterton octopus junction, a variation on the conventional clover-leaf type". There are in all fifteen bridges on this northern approach, of which the Masterton octopus junction accounts for no fewer than six. Part of the latter construction, a 600 -ft. reinforced concrete viaduct, is featured, as also, by contrast, is the slender 3 -span concrete over-pass at Dunfermline Wynd.

\section{International Congress of Plant Pathology}

Following discussions at the International Botanical Congress held at Edinburgh in 1964, arrangements are being made to hold an International Congress of Plant
Pathology at Imperial College, London, S.W.7, England, during the last two weeks of July 1968. The members of the executive committee formed to arrange the congress are as follows: Dr. S. D. Garrett (chairman); Prof. R. K. S. Wood (secretary); Mr. F. C. Bawden; Prof. P. W. Brian; Prof. N. A. Burges; Dr. P. H. Gregory; Dr. J. L. Harley; Dr. I. Isaac. An advisory committee of plant pathologists from countries other than Britain will help to plan the programme. A notice giving preliminary information about the congress will be eirculated during 1965. Further information may be obtained from Prof. R. K. S. Wood, Imperial College, London, S.W.7, England.

\section{Announcements}

THE second meeting of the Federation of European Biochemical Societies will be held at the University of Vienna during April 21-24. Further information can be obtained from the Federation Secretariat, Alserstrasse 4, Vienna IX.

A symposrum on "Inorganic Single Crystals", arranged by the London Section of the Society of Chemical Industry, will be held in London during April 12-13. Further information can be obtained from the Secretary, Society of Chemical Industry, 14 Belgrave Square, London, S.W.1.

THE forty-sixth annual meeting of the American Geophysical Union will be held in Washington during April 19-22. Further information can be obtained from Mr. W. E. Smith, American Geophysical Union, Suite 506, 1145 19th Street, N.W., Washington, D.C.

THE third research meeting on "High Pressure" will be held at the Imperial College of Science and Technology, London, during April 13-14. Further information can be obtained from C. H. L. Goodman, Materials Synthesis Department, Standard Telecommunication Laboratories, London Road, Harlow, Essex.

THE second conference on "Underwater Archaeology", co-sponsored by the Council of Underwater Archaeology, San Francisco, will be held at the Royal Ontario Museum, University of Toronto, during April 15-17. Furthor information can be obtained from Dr. A. D. Tushingham, Royal Ontario Museum, Univorsity of Toronto.

THE sixth Levinstein Memorial Lecture of the Society of Chemical Industry, entitled "Mutual Interactions between Physical Organic Chemistry and Dye Technology", will be delivered by Prof. H. Zollinger (Swiss Federal Institute of Technology) at the Manchester Literary and Philosophical Society on April 13.

THE nineteenth annual Frequency Control symposium, sponsored by the U.S. Army Electronics Laboratories, will be held in Atlantic City during April 20-22. Further information can be obtained from the Director, U.S. Army Electronies Laboratories, Headquarters, U.S. Army Electronics Command, Fort Monmouth, New Jersey.

THE Institute of Biology has established a Western Branoh based on Bristol to cater for the interests of its members in Gloucestershire, Somerset and Wiltshire. The next meeting is on April 5 at 7.30, in the Medical School, University Walk, Bristol, when Dr. Magnus Pyke of the Distillers Co., Ltd., will speak on "Food of the Future". Further information can be obtained from the branch secretary, Dr. A. J. Abbott, Research Station, Long Ashton, Bristol.

Tre spring meeting of the Western States Section of the Combustion Institute will be held in Hollywood during April 21-23. Subjects under discussion will include: high-energy reactions for chemical synthesis; seeded flames including plasma kinetics; supersonic combustion; combustion engineering problems in stationary power plants. Further information can be obtained from the Secretary, Western States Section of the Combustion Institute, 16902 Bollinger Drive, Pacific Palisades, California. 